\title{
Direct Synthesis of Cyclopropanes from gem-Dialkyl Groups through Double C-H Activation
}

\author{
Antonin Clemenceau, Pierre Thesmar, Maxime Gicquel, Alexandre Le Flohic, and Olivier Baudoin*
}

ABSTRACT: Cyclopropanes are important structural motifs found in numerous bioactive molecules, and a number of methods are available for their synthesis. However, one of the simplest cyclopropanation reactions involving the intramolecular coupling of two $\mathrm{C}-\mathrm{H}$ bonds on gem-dialkyl groups has remained an elusive transformation. We demonstrate herein that this reaction is accessible using aryl bromide or triflate precursors and the

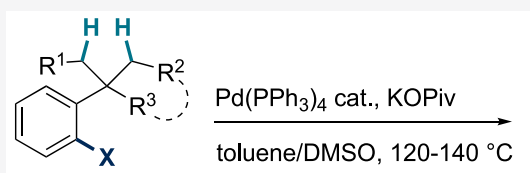

$\mathrm{X}=\mathrm{Br}$ or OTf

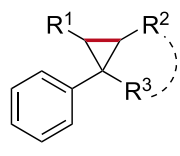

31 examples $45-92 \%$ 1,4-Pd shift mechanism. The use of pivalate as the base was found to be crucial to divert the mechanistic pathway toward the cyclopropane instead of the previously obtained benzocyclobutene product. Stoichiometric mechanistic studies allowed the identification of aryl- and alkylpalladium pivalates, which are in equilibrium via a fivemembered palladacycle. With pivalate, a second $\mathrm{C}\left(\mathrm{sp}^{3}\right)-\mathrm{H}$ activation leading to the four-membered palladacycle intermediate and the cyclopropane product is favored. A catalytic reaction was developed and showed a broad scope for the generation of diverse arylcyclopropanes, including valuable bicyclo[3.1.0] systems. This method was applied to a concise synthesis of lemborexant, a recently approved anti-insomnia drug.

\section{INTRODUCTION}

Cyclopropanes are widespread structural motifs in natural products and bioactive molecules (see Figure 1 for examples). ${ }^{1}$

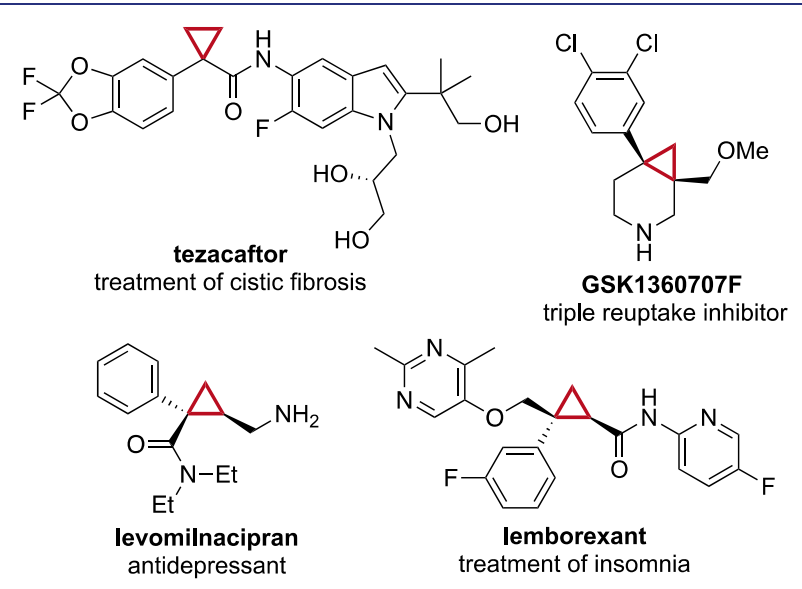

Figure 1. Examples of drugs or drug candidates containing an arylcyclopropane motif relevant to this study.

Indeed, the cyclopropane ring can improve the pharmacological properties of active substances by reducing their lipophilicity, increasing their metabolic stability, or modifying their acido-basicity. ${ }^{2}$ Although a great number of methods have been developed to synthesize cyclopropanes, ${ }^{3}$ the cycloaddition of alkenes and carbenes or carbenoids largely prevails for applications to complex molecules. ${ }^{4}$ In this context, one of the simplest ways to construct cyclopropanes, through $\mathrm{C}-\mathrm{C}$ bond formation from two geminal alkyl groups (Scheme 1a), has remained an elusive transformation to date. In 2006, Yu and co-workers reported the synthesis of cyclopropanes via a two-step sequence involving palladium(II)-catalyzed, oxazoline-directed $\mathrm{C}\left(\mathrm{sp}^{3}\right)-\mathrm{H}$ diiodination of gem-dimethyl groups followed by radical cyclization. (Scheme 1b). ${ }^{5}$ Besides, cyclopropanes have been generated through domino reactions including olefin carbopalladation and $\mathrm{C}\left(\mathrm{sp}^{3}\right)-\mathrm{H}$ activation, leading to putative 4-membered palladacyclic intermediates (Scheme 1c). ${ }^{6,7}$

The current work reports the first single-step synthesis of cyclopropanes via coupling between two geminal methyl groups or one methyl and one activated methylene group (Scheme 1d). This reaction is based on the propension of the arylpalladium halide, generated in the initial oxidative addition step, to undergo 1,4-Pd shift to generate a $\sigma$-alkylpalladium intermediate. ${ }^{8}$ Since seminal observations by Dyker, ${ }^{9}$ such alkylpalladium intermediates have been exploited in various transformations: $\beta-\mathrm{H}$ elimination to generate olefins, ${ }^{10}$ trapping with boronic acids ${ }^{11}$ and anilines, ${ }^{12}$ or intramolecular dearomatizing carbopalladation, furnishing spiroannulation products. ${ }^{13}$ Recently, we showed that such organopalladium species are also able to perform the cleavage of an activated

Received: May 30, 2020

Published: August 12, 2020 
Scheme 1. Synthesis of Cyclopropanes by Pd-Catalyzed $\mathrm{C}\left(\mathrm{sp}^{3}\right)-\mathrm{H}$ Activation

a) elusive transformation<smiles>[R]CC([R7])(C([R])[R])C([R])[R]</smiles>

b) cyclopropanes via double $\mathrm{C}\left(\mathrm{sp}^{3}\right)-\mathrm{H}$ iodination and radical cyclization $\stackrel{\text { Me }}{\mathrm{Me}} \underset{\mathrm{IOAc}}{\stackrel{\text { Pd" cat. }}{\longrightarrow}}$

c) cyclopropanes via alkene carbopalladation and $\mathrm{C}\left(\mathrm{sp}^{3}\right)-\mathrm{H}$ activation

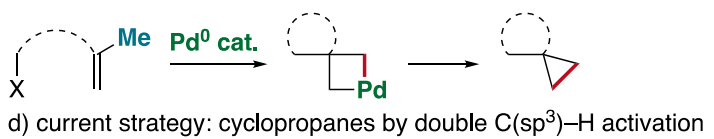

d) current strategy: cyclopropanes by double $\mathrm{C}\left(\mathrm{sp}^{3}\right)-\mathrm{H}$ activation

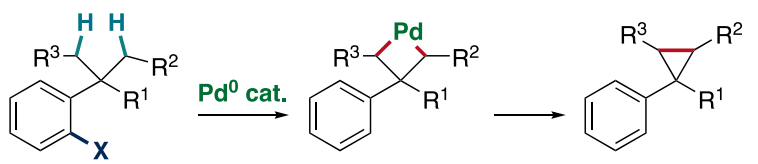

$\mathrm{X}=\mathrm{Br}$, OTf

$\mathrm{R}^{2}, \mathrm{R}^{3}=\mathrm{H}$ or $\mathrm{CH}_{2} \mathrm{EWG}$ (EWG = electron-withdrawing group)

$\mathrm{C}\left(\mathrm{sp}^{3}\right)-\mathrm{H}$ bond (i. e., benzylic and adjacent to a carbonyl group) to generate oxygen and nitrogen heterocycles. ${ }^{14}$ The extension of this mechanism to the formation of cyclopropanes is reported herein.

RESULTS AND DISCUSSION

Initial Work and Mechanistic Study. The origin of this work stems from our initial studies on the generation of

Scheme 2. Influence of the Base on the Formation of Benzocyclobutene vs Cyclopropane<smiles>CC(=O)C(C)(C)c1ccccc1Br</smiles>

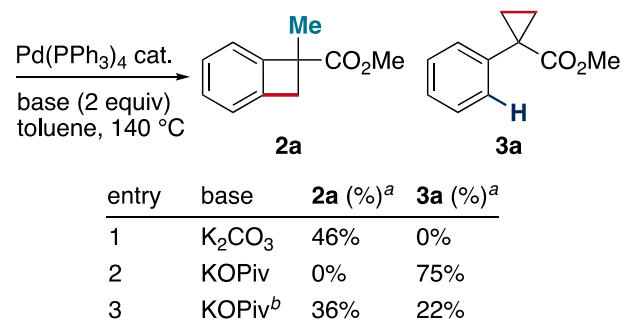

${ }^{a 1} \mathrm{H}$ NMR yield using $\mathrm{CH}_{2} \mathrm{Br}_{2}$ as internal reference. ${ }^{b}$ Using $\mathrm{Pd}_{2} \mathrm{dba}_{3}$ $(5 \mathrm{~mol} \%) / \mathrm{P}(t-\mathrm{Bu})_{3}(20 \mathrm{~mol} \%)$ instead of $\mathrm{Pd}\left(\mathrm{PPh}_{3}\right)_{4}$.

benzocyclobutenes (BCBs) by $\mathrm{Pd}^{0}$-catalyzed $\mathrm{C}\left(\mathrm{sp}^{3}\right)-\mathrm{H}$ activation. ${ }^{15}$ Recent reinvestigations pointed to a spectacular influence of the base on the reaction outcome (Scheme 2). As initially reported, using potassium carbonate as the base in the intramolecular $\mathrm{C}-\mathrm{H}$ arylation of substrate 1a under the shown conditions provided $\mathrm{BCB} \mathbf{2 a}$ as the sole observable $\mathrm{C}-\mathrm{H}$ activation product (entry 1), together with the protodehalogenated byproduct (not shown). Replacing carbonate with pivalate led to a complete change of selectivity, with cyclopropane $3 \mathrm{a}$ becoming the sole $\mathrm{C}-\mathrm{H}$ activation product (entry 2). The ligand also had a noticeable effect on the selectivity, with the bulky $\mathrm{P}(t-\mathrm{Bu})_{3}$ favoring the $\mathrm{BCB}$ product, as previously reported (entry 3$)^{15}$

Following these initial observations, and inspired from a study by Martin and co-workers, ${ }^{16}$ we decided to reinvestigate the reaction mechanism by following each step through stoichiometric experiments (see the Supporting Information for details). A tentative mechanism, represented in qualitative energy profile format, is displayed in Figure 2. The oxidative addition of prototypical aryl bromide $\mathbf{1 b}$ to $\mathrm{Pd}\left(\mathrm{PPh}_{3}\right)_{4}$ gives rise to complex $\mathbf{A}$, which undergoes bromide substitution with pivalate, producing complex $\mathbf{B}^{1}$. The latter is in equilibrium with complex $\mathbf{B}^{2}$, containing one phosphine ligand and pivalate coordinated in the $\kappa^{2}$ mode, ${ }^{17 \mathrm{c}}$ which undergoes base-mediated $\mathrm{C}\left(\mathrm{sp}^{3}\right)-\mathrm{H}$ activation via the concerted metalation-deprotonation mechanism ${ }^{15,17}$ to give five-membered palladacycle $\mathbf{C}^{\mathbf{1}}$. Reductive elimination from $\mathbf{C}^{\mathbf{1}}$ provides the $\mathrm{BCB}$ product $\mathbf{2} \mathbf{b}$. Alternatively, protonation of $\mathbf{C}^{\mathbf{1}}$ with pivalic acid ${ }^{15,17 \mathrm{e}}$ furnishes alkylpalladium complex $\mathbf{D}^{1}$. The sequence $\mathbf{B}^{1} \rightarrow \mathbf{C}^{\mathbf{1}} \rightarrow \mathbf{D}^{1}$ results in an overall 1,4-Pd shift. ${ }^{8,14}$ A second base-induced $\mathrm{C}\left(\mathrm{sp}^{3}\right)-\mathrm{H}$ activation from $\mathbf{D}^{1}$ leads to the rare four-membered palladacycle $\mathbf{E}^{1,6,7,18}$ already suggested by Martin, ${ }^{16}$ which reductively eliminates to generate cyclopropane $\mathbf{3 b}$.

The oxidative addition of the bulky aryl bromide $\mathbf{1 b}$ was followed by ${ }^{1} \mathrm{H}$ and ${ }^{31} \mathrm{P}$ NMR and was found to be slow using $\mathrm{PPh}_{3}$ as the ligand, with only $26 \%$ of complex A formed at 80 ${ }^{\circ} \mathrm{C}$ after $16 \mathrm{~h}$, and $72 \%$ at $120{ }^{\circ} \mathrm{C}$ together with $20 \%$ remaining starting material (Scheme 3a). Complex A was independently synthesized in $88 \%$ yield from $\mathbf{1 b}$ and $\mathrm{Pd}\left(\mathrm{PPh}_{3}\right)_{4}$ (toluene, 120 ${ }^{\circ} \mathrm{C}$ ), and its three-dimensional structure was confirmed by $\mathrm{X}$ ray diffraction analysis (Scheme 3 ). Consistent with results displayed in Scheme 2, heating A to $100{ }^{\circ} \mathrm{C}$ in the presence of $\mathrm{K}_{2} \mathrm{CO}_{3}$ furnished $\mathrm{BCB} \mathbf{2 b}$ in $65 \%$ yield (Scheme $3 \mathrm{~b}$ ). The substitution step was then analyzed by mixing complex A with KOPiv (Scheme 3b). This step was relatively easy, with $\sigma$ arylpalladium pivalate $\mathbf{B}^{\mathbf{1}}$ being slowly formed at room temperature (25\% after $16 \mathrm{~h}$, not shown) and in $82 \%$ yield at $60{ }^{\circ} \mathrm{C}$. Raising the temperature to 80 and $100{ }^{\circ} \mathrm{C}$ led to the formation of cyclopropane $\mathbf{3 b}$ at the expense of complex $\mathbf{B}^{\mathbf{1}}$. This result shows that the formation of the cyclopropane product is faster than the oxidative addition and, therefore, that the latter is the slowest step of the reaction. The reaction of the known $\sigma$-alkylpalladium complex $\left(\mathrm{PhCMe}_{2} \mathrm{CH}_{2}\right) \mathrm{Pd}(\mathrm{COD}) \mathrm{Cl}$ $\mathbf{D}^{2}$ (COD = cyclooctadiene $)^{19}$ in the presence of KOPiv and $\mathrm{PPh}_{3}$ in toluene at room temperature led to alkylpalladium pivalate $\mathbf{D}^{1}$ in $88 \%$ yield (Scheme $\mathrm{S} 1$, see Figure 2 or Scheme 3 for the structure of $\mathrm{D}^{1}$ ). In contrast, at $60{ }^{\circ} \mathrm{C}$ arylpalladium pivalate $\mathbf{B}^{1}$ was formed from $\mathbf{D}^{2}$, thus showing that $\mathbf{B}^{1}$ is more stable than $\mathbf{D}^{1}$. The thermal decomposition of $\mathbf{B}^{\mathbf{1}}$ was next analyzed at various temperatures (Scheme $3 \mathrm{c}$ ). At $80{ }^{\circ} \mathrm{C}$, both $D^{1}$ and cyclopropane $3 \mathbf{b}$ were formed, and the proportion of cyclopropane markedly increased at $100{ }^{\circ} \mathrm{C}$. The reactivity of alkylpalladium pivalate $\mathbf{D}^{1}$ was also analyzed (Scheme $3 \mathrm{~d}$ ). At $80{ }^{\circ} \mathrm{C}$, a new complex, which was assigned to arylpalladium species $\mathbf{B}^{2}$ containing one $\mathrm{PPh}_{3}$ ligand and the $\kappa^{2}$-coordinated pivalate, was formed together with degradation products. Adding $\mathrm{PPh}_{3}$ (1 equiv) led to a cleaner transformation, with both mono- and bis-ligated complexes $\mathbf{B}^{\mathbf{1}}-\mathbf{B}^{\mathbf{2}}$ and cyclopropane $\mathbf{3 b}$ being formed in comparable amounts. Heating this mixture to $100{ }^{\circ} \mathrm{C}$ furnished a higher proportion of $\mathbf{B}^{2}$ and cyclopropane $3 \mathbf{b}$, and upon addition of 1 equiv of KOPiv the cyclopropane was formed exclusively. These results show that aryl- and alkylpivalate complexes $\mathbf{B}^{\mathbf{1}}, \mathbf{B}^{\mathbf{2}}$ and $\mathbf{D}^{\mathbf{1}}$ are in equilibrium from $80^{\circ} \mathrm{C}$ and are all competent intermediates en route to cyclopropane $3 \mathrm{~b}$. Finally, since we did not observe the formation of five-membered palladacycles such as $\mathbf{C}^{\mathbf{1}}$ (Figure 2) during the above studies, likely because they are higherenergy intermediates, we decided to prepare the known ${ }^{20}$ fivemembered COD-stabilized palladacycle $\mathbf{C}^{2}$ and study its reactivity (Scheme 3e). In the presence of KOPiv, PivOH, 


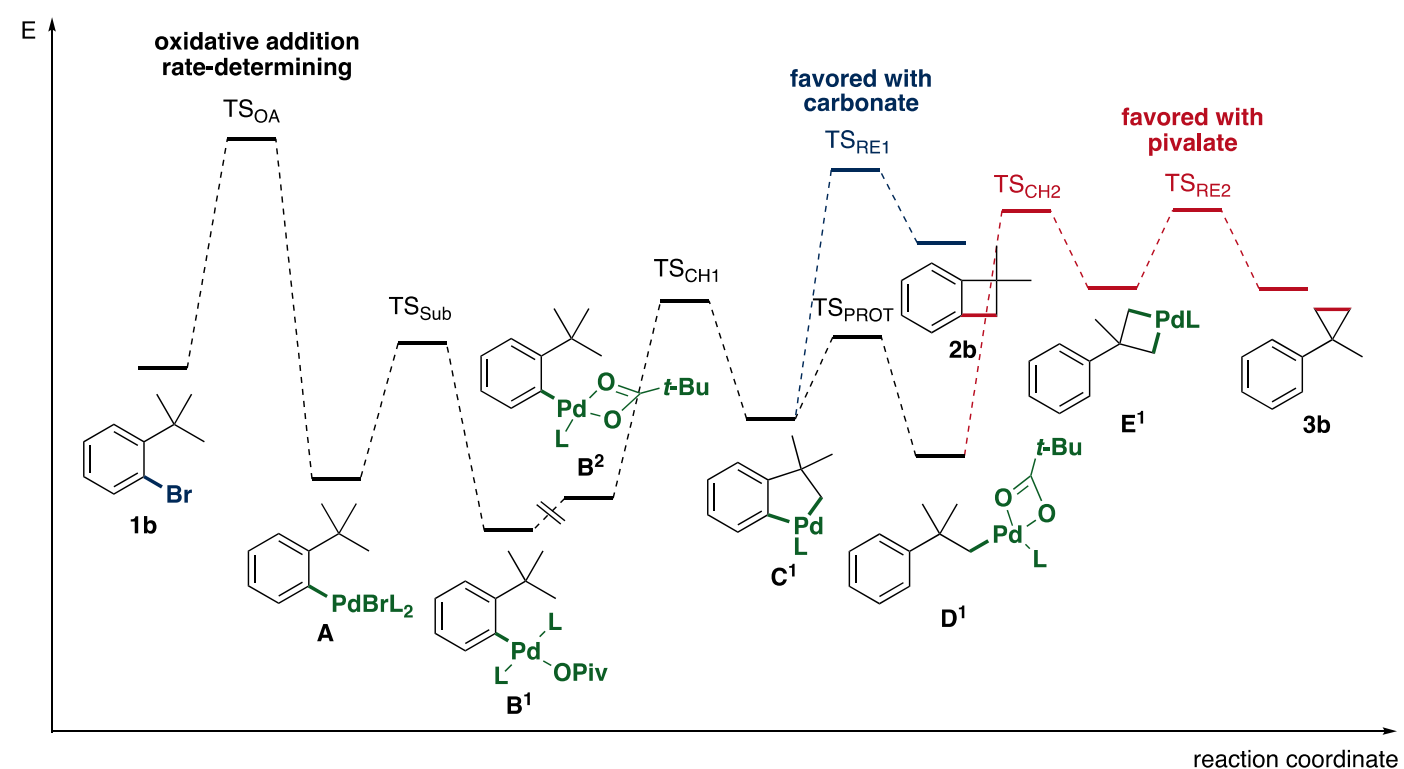

Figure 2. Qualitative energy profile of the reaction of substrate $\mathbf{1 b}$ based on experimental observations. The relative stabilities of $\mathbf{B}^{2}$ and $\mathbf{D}^{1}, \mathbf{C}^{1}$ and $\mathbf{E}^{1}$, and $\mathbf{2 b}$ and $\mathbf{3 b}$ were calculated by DFT (see the Supporting Information for details). $\mathrm{L}=\mathrm{PPh}_{3}$. TS = transition state; OA = oxidative addition; $\mathrm{Sub}=$ substitution; $\mathrm{CH}=\mathrm{C}-\mathrm{H}$ activation; $\mathrm{PROT}=$ protonation; $\mathrm{RE}=$ reductive elimination.

Scheme 3. Stepwise Study of the Reaction Mechanism through Stoichiometric Experiments ${ }^{a}$

a)<smiles>CC(C)(C)c1ccccc1Br</smiles>

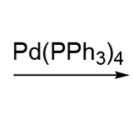<smiles>CCCCC(C)(C)c1ccccc1CC</smiles>

$\begin{array}{ll}60{ }^{\circ} \mathrm{C} & 1 \mathrm{~b} \\ 800^{\circ} \mathrm{C} & 74 \% \\ 100^{\circ} \mathrm{C} & 45 \%\end{array}$

$100^{\circ} \mathrm{C} 45 \%$

c)<smiles>CC(C)(C)c1ccccc1Br</smiles>
$\mathrm{Pd}\left(\mathrm{PPh}_{3}\right)_{2} \mathrm{OPiv}$ $\mathrm{B}^{1}$ $80^{\circ} \mathrm{C} \quad 27 \%$

d)$$
72 \%
$$

b)

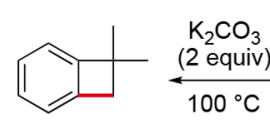

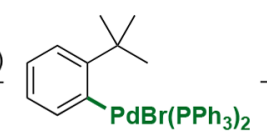

KOPiv (2 equiv)
$\begin{array}{lccc}\mathbf{P d B r}\left(\mathrm{PPh}_{3}\right)_{2} & & 100^{\circ} \mathrm{C} & \\ \mathbf{A} & \mathbf{2 b} & & \mathbf{P d} \\ 0 \% & 65 \% & 60{ }^{\circ} \mathrm{C} & 10 \% \\ 26 \% & & 80^{\circ} \mathrm{C} & 0 \%\end{array}$ $80{ }^{\circ} \mathrm{C} \quad \% \%$

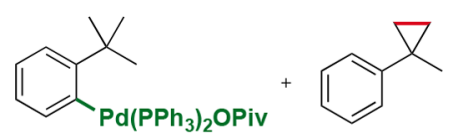

$\mathrm{B}^{1} \quad 3 \mathrm{~b}$ $\begin{array}{ll}82 \% & 0 \% \\ 76 \% & 14 \%\end{array}$

\begin{tabular}{l}
$2 \%$ \\
$14 \%$ \\
\hline
\end{tabular}

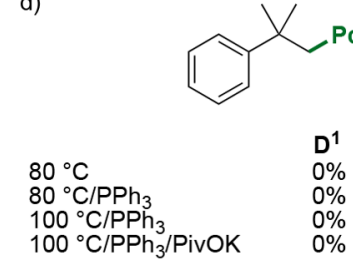

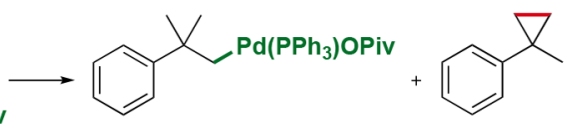

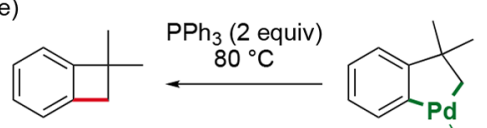

$2 b$
$78 \%$ $c^{2}$ COD

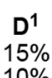

$15 \%$
$10 \%$
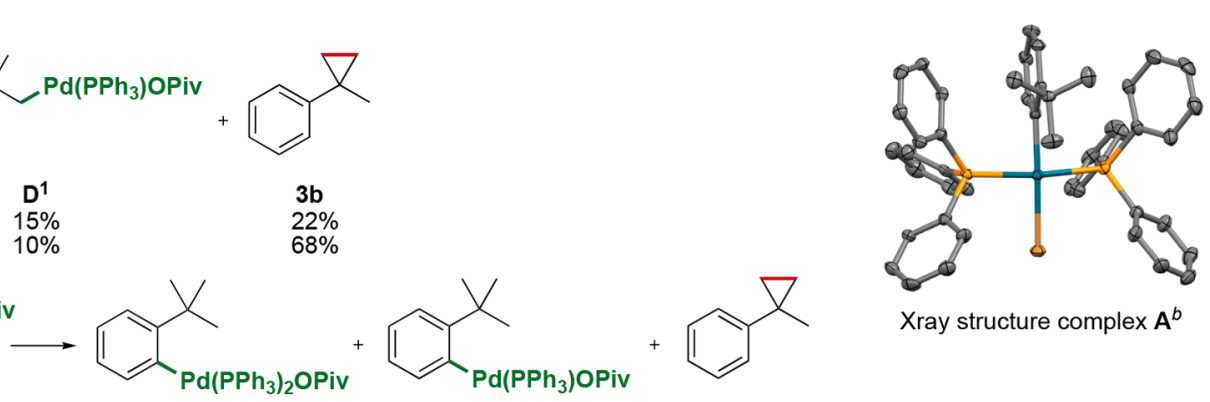

Xray structure complex $\mathbf{A}^{b}$
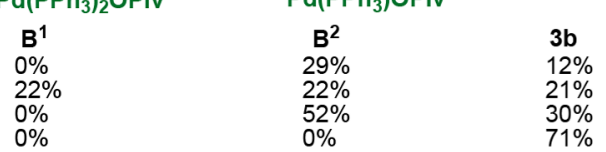

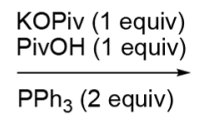

$\mathrm{PPh}_{3}$ (2 equiv)

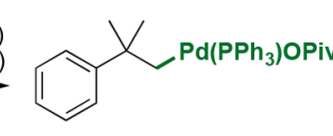

$\begin{array}{cc} & \mathbf{D}^{\mathbf{1}} \\ 20^{\circ} \mathrm{C} & 85 \% \\ 80^{\circ} \mathrm{C} & 20 \% \\ 100^{\circ} \mathrm{C} & 0 \%\end{array}$

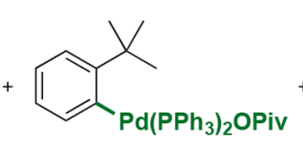

$\mathbf{B}^{\mathbf{1}}$
$12 \%$
$56 \%$
$0 \%$<smiles>CCC(C)(C)c1ccccc1</smiles>

$\mathbf{3 b}$
$0 \%$

$11 \%$

${ }^{a 1} \mathrm{H}$ NMR yields using $\mathrm{CH}_{2} \mathrm{Br}_{2}$ as internal reference. All reactions were performed in $\mathrm{C}_{6} \mathrm{D}_{6}$ for 16 h. ${ }^{b}$ Thermal ellipsoids at $50 \%$ probability, $\mathrm{H}$ atoms omitted for clarity. $\mathrm{COD}=1,5$-cyclooctadiene.

and $\mathrm{PPh}_{3}$ at room temperature, complex $\mathbf{D}^{1}$ was formed as major product, together with minor amounts of $\mathbf{B}^{1}$, thereby showing that the protonation with $\mathrm{PivOH}$ is kinetically favored on the aromatic vs the alkyl ligand. Heating to $80{ }^{\circ} \mathrm{C}$ inversed the ratio between $\mathbf{D}^{1}$ and $\mathbf{B}^{1}$, thus confirming the higher thermodynamic stability of $\mathbf{B}^{\mathbf{1}}$, and produced a minor amount of cyclopropane $3 \mathbf{b}$. At $100{ }^{\circ} \mathrm{C}$, only the latter was formed (61\% yield). In contrast, heating palladacycle $\mathrm{C}^{2}$ to $80{ }^{\circ} \mathrm{C}$ in the presence of $\mathrm{PPh}_{3}$ only provided BCB $\mathbf{2 b}$ in good yield. ${ }^{16}$

Taken together, these experimental observations allow to deduce the following relative stabilities for organopalladium complexes: $\mathbf{B}^{1}>\mathbf{B}^{2}>\mathbf{D}^{1}>\mathbf{C}^{1}$. In addition, DFT calculations 
Scheme 4. Reaction Scope ${ }^{a}$

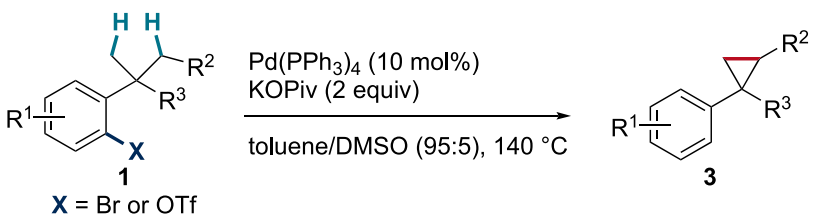

a) disubstituted cyclopropanes $\left(\mathrm{R}^{2}=\mathrm{H}\right)$<smiles>CC1(c2ccccc2)CC1</smiles>

3b, $(98 \%)^{b, c}$<smiles></smiles>

$\mathrm{R}=\mathrm{Me}: \mathbf{3 a}, 76 \%^{d}$<smiles>CNC(=O)C(C)(C)c1ccccc1</smiles>

3d, $76 \%$<smiles>CC(C)(CN)c1ccccc1</smiles>

$3 e, 80 \%$

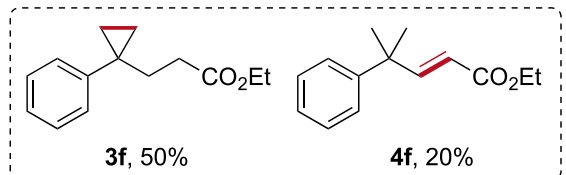

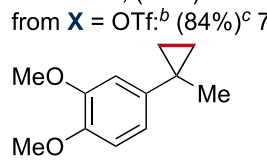

$3 \mathrm{~g}, 81 \%$<smiles>COc1ccc(C2(C(C)=O)CC2)cc1OC</smiles>

$3 h, 75 \%$<smiles>COc1ccc(C2(CO[I+3])CC2)cc1OC</smiles>

3i, $72 \%$

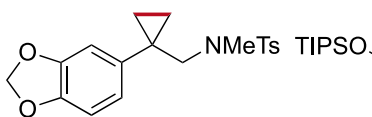

3j, $71 \%$<smiles>Fc1cccc(C2(CO[Na])CC2)c1</smiles>

$3 \mathrm{~m}, 85 \%$<smiles>COC(OC)C1(c2cccc([N+](=O)[O-])c2)CC1</smiles>

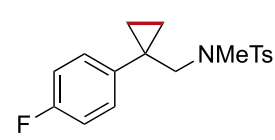

3o, $73 \%$

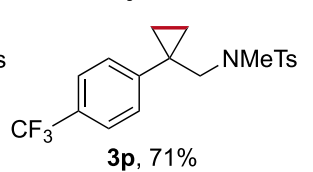

$3 p, 71 \%$

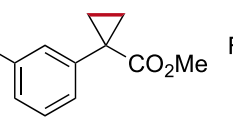

3k, $65 \%$<smiles>COC(=O)C1(c2cccc(F)c2)CC1</smiles>

$31,69 \%$<smiles>Cc1cc(C(C)(C)C)cc(C2(C)CC2)c1</smiles><smiles>CC(C)(C)c1cc(C(C)(C)C)cc(C2(C)CC2)c1</smiles><smiles>CC1(c2cccc(C3(C)CC3)c2)CC1</smiles>

from $X=$ OTf: $3 u, 92 \%$

b) trisubstituted cyclopropanes $\left(R^{2} \neq H\right)$

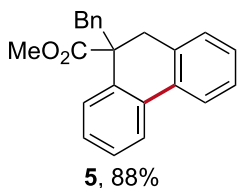

$C\left(s p^{2}\right)-H$ arylation

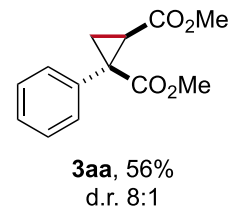

d.r. $8: 1$

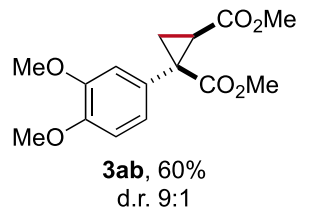

d.r. $9: 1$
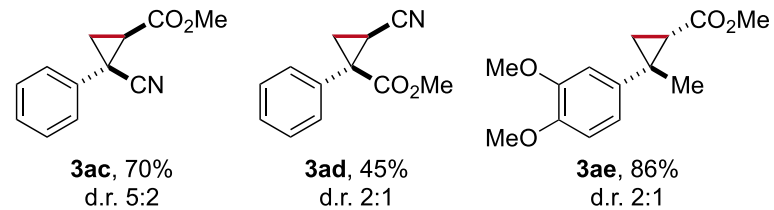

${ }^{a}$ Reactions were performed on a $0.2 \mathrm{mmol}$ scale. The aryl bromide precursor was employed unless otherwise noted. Yields refer to the isolated product or mixture of diastereoisomers. Diastereomeric ratios (d.r.) were determined by ${ }^{1} \mathrm{H}$ NMR of the crude mixture. Relative configurations were determined by NOESY NMR. ${ }^{b}$ Performed at $120{ }^{\circ} \mathrm{C}$ without DMSO. ${ }^{c 1} \mathrm{H}$ NMR yield using $\mathrm{CH}_{2} \mathrm{Br}_{2}$ as internal reference. ${ }^{d} \mathrm{Performed}$ on a 1 mmol scale using $o$-xylene as the solvent.

indicated that the four-membered palladacycle $\mathbf{E}^{1}$ is less stable than the five-membered isomer $\mathbf{C}^{1}$ by ca. $7 \mathrm{kcal} \mathrm{mol}^{-1}$, hence establishing the stability order $\mathbf{B}^{1}>\mathbf{B}^{2}>\mathbf{D}^{1}>\mathbf{C}^{1}>\mathbf{E}^{1}$. Furthermore, cyclopropane $\mathbf{3 b}$ was found to be more stable than $\mathrm{BCB} 2 \mathbf{2 b}$ by $1.7 \mathrm{kcal} \mathrm{mol}^{-1}$. Figure 2 provides a qualitative overview of the reaction profile summarizing all experimental results and calculations. The oxidative addition is the highest kinetic barrier, which arises from the fact that the relatively electronically neutral $\mathrm{PPh}_{3}$ was employed as ligand. In the presence of carbonate and the absence of pivalate, reductive elimination from five-membered palladacycle $\mathbf{C}^{\mathbf{1}}$ occurs preferentially to give $\mathrm{BCB}$ product $\mathbf{2} \mathbf{b}$. In contrast, pivalate promotes the formation of cyclopropane $3 \mathbf{b}$ via $\mathrm{C}\left(\mathrm{sp}^{3}\right)-\mathrm{H}$ activation of a second methyl group producing the fourmembered palladacycle intermediate $\mathbf{E}^{1}$. Both bicarbonate ${ }^{21}$ and pivalic acid are able to open up palladacycle $\mathbf{C}^{1}$ to give alkylpalladium intermediates, and therefore the unique ability of pivalate to promote the second $\mathrm{C}\left(\mathrm{sp}^{3}\right)-\mathrm{H}$ activation event leading to cyclopropanation remains unclear and will be the object of later studies.

Reaction Optimization and Scope. Taking advantage of the above mechanistic study, a catalytic version of this transformation was successfully developed (see the Supporting
Information for details). Unsubstituted cycloproprane $\mathbf{3 b}$ was obtained from both aryl bromide and triflate precursors in good yield using $10 \mathrm{~mol} \% \mathrm{Pd}\left(\mathrm{PPh}_{3}\right)_{4}$ and 2 equiv potassium pivalate in toluene at $120{ }^{\circ} \mathrm{C}$ (Scheme 4a). However, this volatile product was best isolated from the triflate precursor in $72 \%$ yield. For functionalized cyclopropanes, a temperature of $140{ }^{\circ} \mathrm{C}$ was essential to ensure complete conversion. Besides, the addition of DMSO ( $5 \%$ vol.) was found to diminish the formation of the proto-dehalogenated side-product, presumably by increasing the solubility of pivalate.

With these standard conditions in hand, the versatility of this double $\mathrm{C}\left(\mathrm{sp}^{3}\right)-\mathrm{H}$ activation-based cyclopropanation was inspected. Substrates bearing an ester ( $3 a$ and $3 c$ ), amide (3d), protected amine (3e), or protected alcohol (3i and $\mathbf{3 m}$ ) on the quaternary benzylic carbon worked well under the optimized conditions $(72-85 \%$ yields). Of note, the reaction producing cyclopropane $3 \mathrm{a}$ was successfully scaled up to 1 mmol using $o$-xylene as the solvent for practical reasons. In addition, substrate If bearing a substituted linear alkyl chain provided a mixture of the desired cyclopropane $3 \mathrm{f}$ ( $50 \%$ yield) and olefin $\mathbf{4 f}$ arising from methylene $\mathrm{C}-\mathrm{H}$ activation and $\beta-\mathrm{H}$ elimination, consistent with previous work. ${ }^{10 a, 17 \mathrm{e}}$ Reactants containing various electron-donating groups on the aromatic 
Scheme 5. Synthesis of Cyclopropane-Fused Lactones and Lactams
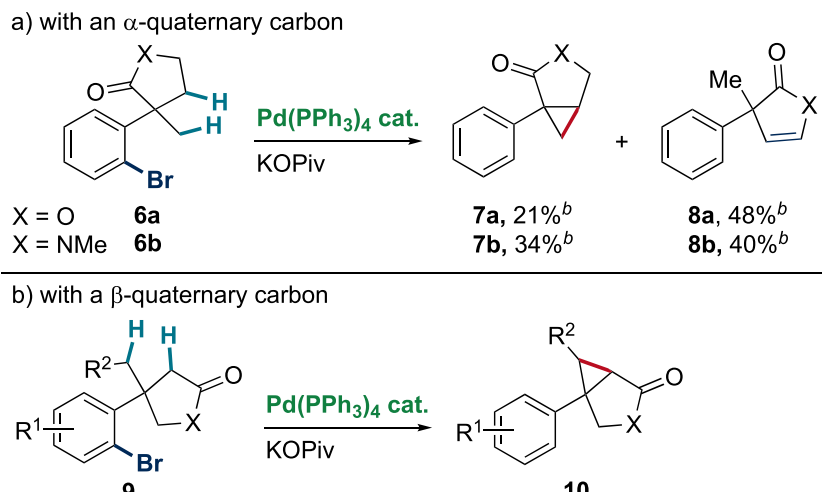

$\underset{\mathrm{KOPiv}}{\stackrel{\mathrm{Pd}\left(\mathrm{PPh}_{3}\right)_{4} \text { cat. }}{\longrightarrow}}$
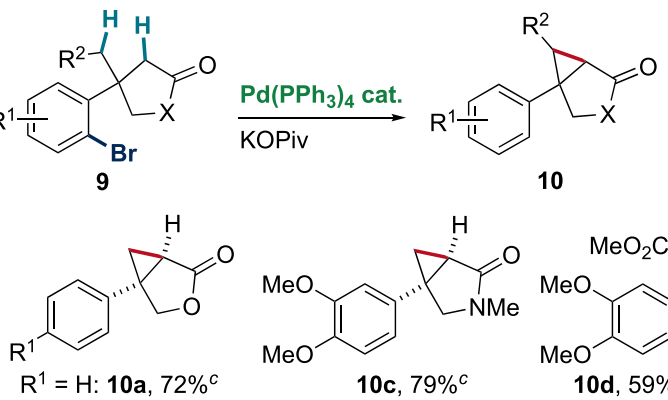

$\mathrm{R}^{1}=$ OMe: $10 \mathrm{~b}, 65 \%{ }^{c}$
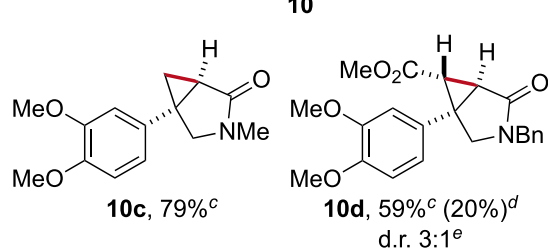

${ }^{a}$ Conditions: $\operatorname{Pd}\left(\mathrm{PPh}_{3}\right)_{4}(10 \mathrm{~mol} \%)$, KOPiv (2 equiv), toluene/ DMSO (95:5), $140{ }^{\circ} \mathrm{C}, 16 \mathrm{~h} .{ }^{b} \mathrm{NMR}$ yield. ${ }^{c}$ Yield of the isolated product. ${ }^{d}$ Yield of the isolated minor diastereoisomer. ${ }^{e}$ Ratio determined by ${ }^{1} \mathrm{H}$ NMR of the crude mixture, relative configuration determined by NOESY NMR.

ring such as dimethoxy $(3 \mathbf{g}-\mathbf{i})$, methylenedioxy $(3 \mathbf{j})$, or TIPSprotected phenol $(3 \mathrm{k})$ gave the desired cyclopropanes in good yields $(65-81 \%)$. Likewise, electron-withdrawing groups such as fluoro (31, 3m, and 3o), nitro (3n), and trifluoromethyl (3p) were found to be compatible. The position of the substituent on the aromatic ring (meta or para) did not have a significant influence on the reaction outcome. In addition, the pyridinylcyclopropane $\mathbf{3 q}$ was generated in $70 \%$ yield, hence indicating the compatibility of heteroarenes. Moreover, substrates functionalized in ortho position to the quaternary carbon $(\mathbf{1 r})$ or to the bromine atom $(\mathbf{1 s}$ and $\mathbf{1 t})$ provided the corresponding cyclopropane products $3 \mathbf{r}-\mathbf{t}$ in good yields (69-78\%). Remarkably, a 2-fold cyclopropanation reaction was successfully carried out, allowing formation of biscyclopropane $3 \mathbf{u}$ in $92 \%$ yield via two consecutive cyclopropanations including four $\mathrm{C}\left(\mathrm{sp}^{3}\right)-\mathrm{H}$ activation steps.

As expected, substrates bearing benzyl instead of methyl groups did not undergo $\mathrm{C}\left(\mathrm{sp}^{3}\right)-\mathrm{H}$ activation and cyclopropanation, but rather direct $\mathrm{C}\left(\mathrm{sp}^{2}\right)-\mathrm{H}$ arylation, as illustrated with the 6-membered ring product 5 (Scheme $4 \mathrm{~b}$ ). In contrast, in the case of substrates bearing a quaternary carbon with one methyl and one methylene adjacent to an ester or nitrile group, the construction of trisubstituted cyclopropanes was possible. First, cyclopropanes $3 \mathrm{aa}$ and $3 \mathrm{ab}$ containing two esters were synthesized in average yields and good diastereoselectivity, probably arising from thermodynamic control. The positional isomers 3ac and 3ad containing nitrile groups were also produced, albeit with a reduced diastereoselectivity. Finally, the trisubstituted cyclopropane 3ae was generated in $86 \%$ combined yield and with a weak, but opposite diastereoselectivity compared to $3 \mathrm{ab}$.

Molecules containing an aryl-substituted [3.1.0] bicyclic system show interesting biological activities, ${ }^{2}$ but only a few methods have been developed for their synthesis ${ }^{22-26}$ The access to these attractive scaffolds was investigated by applying
Scheme 6. Application to the Synthesis of Lemborexant ${ }^{a}$<smiles>C=CCC(C)(OC)c1cc(F)ccc1Br</smiles><smiles>O=C1OC[C@]2(c3cccc(F)c3)C[C@H]12</smiles>

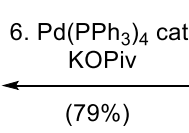

$(79 \%)$

$10 e$<smiles>[Z6]c1ccc(N)nc1</smiles><smiles>Cc1ccc(NC(=O)C2C[C@]2(CO)c2cccc(F)c2)nc1</smiles>

15

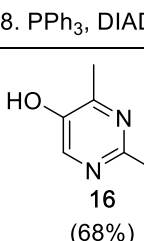

$(68 \%)$<smiles>CC1(c2cc(F)ccc2Br)COC(=O)C1</smiles>

$9 e$
${ }^{a}$ Conditions: $1 . \mathrm{MeOH}, \mathrm{H}_{2} \mathrm{SO}_{4}$ (0.1 equiv), $50{ }^{\circ} \mathrm{C}$; 2. LDA (1.2 equiv), $\mathrm{MeI}$ ( 1.05 equiv), -78 to $+25^{\circ} \mathrm{C}$; 3 . LiHMDS (3 equiv), allyl bromide ( 5 equiv), THF, 0 to $25{ }^{\circ} \mathrm{C}$ ( $72 \%$ for 3 steps); 4. DIBAL-H (2.1 equiv), $\mathrm{Et}_{2} \mathrm{O},-78$ to $+25{ }^{\circ} \mathrm{C}(82 \%) ; 5 . \mathrm{RuCl}_{3}(5 \mathrm{~mol} \%), \mathrm{NaIO}_{4}$ (6 equiv), $\mathrm{MeCN} / \mathrm{H}_{2} \mathrm{O} 10: 1,25{ }^{\circ} \mathrm{C} ; 6 . \mathrm{Pd}\left(\mathrm{PPh}_{3}\right)_{4}(10 \mathrm{~mol} \%)$, KOPiv (2 equiv), o-xylene/DMSO 95:5, $140{ }^{\circ} \mathrm{C}$; 7. LiHMDS (3 equiv), 14 ( 3 equiv), toluene, $25^{\circ} \mathrm{C}(89 \%) ; 8.16$ (1.5 equiv), $\mathrm{PPh}_{3}$ (1.5 equiv), DIAD (1.5 equiv), THF, $25^{\circ} \mathrm{C}(68 \%)$.

our newly developed Pd-catalyzed double $\mathrm{C}\left(\mathrm{sp}^{3}\right)-\mathrm{H}$ activation reaction (Scheme 5). Starting from lactone $\mathbf{6 a}$, the cyclopropane-fused product $7 \mathbf{a}$ was formed in low yield and the major product was the butenolide 8a resulting from $\beta$ hydrogen elimination (Scheme 5a). A similar result was obtained from lactam $\mathbf{6}$ b. To suppress the olefin formation, the reaction was conducted with $\gamma$-lactones and lactams 9 bearing the quaternary carbon in $\beta$ position to the carbonyl group (Scheme 5b). Gratifyingly, this modification led to the cyclopropane-fused lactones $10 \mathbf{a}-\mathbf{b}$ and lactam $10 \mathrm{c}$ in $65-$ $79 \%$ yields. To further increase the complexity, a more substituted substrate bearing a $\mathrm{CH}_{2} \mathrm{CO}_{2} \mathrm{Me}$ instead of the $\mathrm{CH}_{3}$ group was employed. A separable 3:1 diastereomeric mixture of fused $\gamma$-lactams was obtained in $79 \%$ combined yield, with the major diastereoisomer 10c having the aryl and ester groups in cis relationship. This example shows that our methodology can also be employed to couple two activated methylene groups for the synthesis of tetrasubstituted cyclopropanes.

Lemborexant 11 (Dayvigo, Figure 1) is a dual antagonist of the orexin $\mathrm{OX}_{1}$ and $\mathrm{OX}_{2}$ receptors, which was recently approved for the treatment of insomnia. ${ }^{27}$ The application of the current method to a short synthesis of this bioactive target is depicted in Scheme 6. Esterification of commercially available aryl bromide $\mathbf{1 2}$ and sequential alkylation and allylation led to methyl ester 13. The latter was subjected to ester reduction and oxidative cleavage of the alkene, which 
directly provided $\gamma$-butyrolactone $9 \mathrm{e}^{28}$ The key cyclopropanation of $9 \mathrm{e}$ was performed under the optimized conditions, to furnish the fused lactone 10e in good yield (79\%). Direct amidation of the latter with aminopyridine 14 and LiHMDS according to Szostak and co-workers, ${ }^{29}$ followed by Mitsunobu reaction with pyrimidinol 16 furnished racemic lemborexant 11 in $28 \%$ overall yield over 8 steps.

\section{CONCLUSIONS}

The elusive intramolecular cyclopropanation reaction cleaving two $\mathrm{C}-\mathrm{H}$ bonds and forging a $\mathrm{C}-\mathrm{C}$ bond has been developed by taking advantage of the 1,4-Pd shift mechanism. Stoichiometric studies indicated that oxidative addition is the rate-limiting step with the employed substrates and catalyst. The characterization of intermediate Pd complexes allowed the delineation of a mechanistic pathway including $\sigma$-aryl- and $\sigma$ alkylpalladium pivalates, which are in equilibrium via the fivemembered diorganopalladacycle. With pivalate as the base and $\mathrm{PPh}_{3}$ as the ligand, the reductive elimination from this palladacycle is disfavored and the activation of a second $\mathrm{C}\left(\mathrm{sp}^{3}\right)-\mathrm{H}$ bond is favored, leading to a high-energy fourmembered palladacycle which reductively eliminates to give the cyclopropane product. A catalytic version was developed, which enabled the generation of an array of arylcyclopropanes in good yields, including fused ring systems, from simple aryl bromide or triflate precursors. The generation of fused cyclopropanes was applied to a straightforward synthesis of the anti-insomnia drug lemborexant. This work further illustrates that tuning the catalyst and base in Pd-catalyzed $\mathrm{C}-\mathrm{H}$ activation reactions may allow to divert mechanistic pathways toward the formation of high value-added products.

\section{ASSOCIATED CONTENT}

Full optimization tables, crystallographic, procedural, and spectral data (PDF)

Crystallographic data of a compound as discussed in the text (CIF)

DFT-optimized structures of the compounds as discussed in the text (XYZ)

\section{AUTHOR INFORMATION}

Corresponding Author

Olivier Baudoin - Department of Chemistry, University of

Basel, CH-4056 Basel, Switzerland; 이이.org/0000-0002-

0847-8493; Email: olivier.baudoin@unibas.ch

\author{
Authors \\ Antonin Clemenceau - Department of Chemistry, University of \\ Basel, CH-4056 Basel, Switzerland \\ Pierre Thesmar - Department of Chemistry, University of Basel, \\ CH-4056 Basel, Switzerland \\ Maxime Gicquel - Oril Industrie, 76210 Bolbec, France \\ Alexandre Le Flohic - Oril Industrie, 76210 Bolbec, France
}

\section{Notes}

The authors declare no competing financial interest.

\section{ACKNOWLEDGMENTS}

This work was financially supported by Oril Industrie, affiliated to Les Laboratoires Servier, and the University of Basel. We thank Dr. Lucile Vaysse-Ludot, Dr. R. Tamion, and Dr. J. Fournier, ORIL Industrie, for fruitful discussions and constant support; Dr. D. Häussinger, University of Basel, for NMR experiment; Dr. Alessandro Prescimone, University of Basel, for Xray diffraction analysis; and Dr. M. Pfeffer, University of Basel, for MS analyses.

\section{REFERENCES}

(1) Faust, R. Fascinating Natural and Artificial Cyclopropane Architectures. Angew. Chem., Int. Ed. 2001, 40, 2251-2253.

(2) (a) Talele, T. T. The "Cyclopropyl Fragment" is a Versatile Player that Frequently Appears in Preclinical/Clinical Drug Molecules. J. Med. Chem. 2016, 59, 8712-8756. (b) Časar, Z. Synthetic Approaches to Contemporary Drugs that Contain the Cyclopropyl Moiety. Synthesis 2020, 52, 1315-1345.

(3) (a) Roy, M.-N.; Lindsay, V. N. G.; Charette, A. B. Cyclopropanation Reactions. In Science of Synthesis; De Vries, J. G., Molander, G. A., Evans, P. A., Eds.; Thieme: Stuttgart, 2011; Vol. 1, pp 731-817. (b) Kulinkovich, O. G. Cyclopropanes in Organic Synthesis; John Wiley \& Sons, Inc.: Hoboken, NJ, 2015.

(4) (a) Chen, D. Y.-K.; Pouwer, R. H.; Richard, J.-A. Recent Advances in the Total Synthesis of Cyclopropane-Containing Natural Products. Chem. Soc. Rev. 2012, 41, 4631-4642. (b) Ebner, C.; Carreira, E. M. Cyclopropanation Strategies in Recent Total Syntheses. Chem. Rev. 2017, 117, 11651-11679.

(5) Giri, R.; Wasa, M.; Breazzano, S. P.; Yu, J.-Q. Converting gemDimethyl Groups into Cyclopropanes via Pd-Catalyzed Sequential $\mathrm{C}-\mathrm{H}$ Activation and Radical Cyclization. Org. Lett. 2006, 8, 56855688.

(6) (a) Liron, F.; Knochel, P. Reactivity of Stable Neopentyl-Pd Intermediates in the Absence of Nucleophile. Tetrahedron Lett. 2007, 48, 4943-4946. (b) Kim, H. S.; Gowrisankar, S.; Kim, S. H.; Kim, J. N. Synthesis of 6-Oxacyclopropa[a]indene Derivatives Starting from Baylis-Hillman Adducts via Pd-Mediated $\mathrm{C}\left(\mathrm{sp}^{3}\right)-\mathrm{H}$ Activation. Tetrahedron Lett. 2008, 49, 3858-3861. (c) Huang, Q.; Larock, R. C. Synthesis of Cyclopropanes by Pd-Catalyzed Activation of Alkyl C-H Bonds. Tetrahedron Lett. 2009, 50, 7235-7238. (d) Mao, J.; Zhang, S.-Q.; Shi, B.-F.; Bao, W. Palladium(0)-Catalyzed Cyclopropanation of Benzyl Bromides via $\mathrm{C}\left(\mathrm{sp}^{3}\right)-\mathrm{H}$ Bond Activation. Chem. Commun. 2014, 50, 3692-3694. (e) Du, W.; Gu, Q.; Li, Z.; Yang, D. Palladium(II)-Catalyzed Intramolecular Tandem Aminoalkylation via Divergent $\mathrm{C}\left(\mathrm{sp}^{3}\right)-\mathrm{H}$ Functionalization. J. Am. Chem. Soc. 2015, 137, 1130-1135. (f) Chung, D. S.; Lee, J. S.; Ryu, H.; Park, J.; Kim, H.; Lee, J. H.; Kim, U. B.; Lee, W. K.; Baik, M.-H.; Lee, S.-g. Palladium-Catalyzed Divergent Cyclopropanation by Regioselective Solvent-Driven $\mathrm{C}\left(\mathrm{sp}^{3}\right)-\mathrm{H}$ Bond Activation. Angew. Chem., Int. Ed. 2018, 57, 15460-15464.

(7) For the construction of cyclopropanes via $\mathrm{C}-\mathrm{C}$ activation and $\mathrm{C}\left(\mathrm{sp}^{3}\right)-\mathrm{H}$ activation: Cao, J.; Chen, L.; Sun, F.-N.; Sun, Y.-L.; Jiang, K.-Z.; Yang, K.-F.; Xu, Z.; Xu, L.-W. Pd-Catalyzed Enantioselective Ring Opening/Cross-Coupling and Cylopropanation of Cyclobutanones. Angew. Chem., Int. Ed. 2019, 58, 897-901.

(8) (a) Ma, S.; Gu, Z. 1,4-Migration of Rhodium and Palladium in Catalytic Organometallic Reactions. Angew. Chem., Int. Ed. 2005, 44, 7512-7517. (b) Shi, F.; Larock, R. C. Remote C-H Activation via Through-Space Palladium and Rhodium Migrations. Top. Curr. Chem. 2009, 292, 123-164. (c) Rahim, A.; Feng, J.; Gu, Z. 1,4-Migration of Transition Metals in Organic Synthesis. Chin. J. Chem. 2019, 37, 929-945.

(9) (a) Dyker, G. Palladium-Catalyzed C-H Activation of Methoxy Groups: A Facile Synthesis of Substituted $6 H$-Dibenzo[b,d]pyrans. Angew. Chem., Int. Ed. Engl. 1992, 31, 1023-1025. (b) Dyker, G. Palladium-Catalyzed C-H Activation of tert-Butyl Groups: A Simple Synthesis of 1,2-Dihydrocyclobutabenzene Derivatives. Angew. Chem., 
Int. Ed. Engl. 1994, 33, 103-105. (c) Dyker, G. Palladium-Catalyzed $\mathrm{C}-\mathrm{H}$ Activation at Methoxy Groups: Regiochemistry of the Domino Coupling Process. Chem. Ber. 1994, 127, 739-742.

(10) (a) Baudoin, O.; Herrbach, A.; Guéritte, F. The PalladiumCatalyzed C-H Activation of Benzylic gem-Dialkyl Groups. Angew. Chem., Int. Ed. 2003, 42, 5736-5740. (b) Hitce, J.; Retailleau, P.; Baudoin, O. Palladium-Catalyzed Intramolecular $\mathrm{C}\left(\mathrm{sp}^{3}\right)-\mathrm{H}$ Functionalization: Catalyst Development and Synthetic Applications. Chem. - Eur. J. 2007, 13, 792-799. (c) Motti, E.; Catellani, M. Catalytic Dehydrogenation of o-Alkylated or o-Alkoxylated Iodoarenes with Concomitant Hydrogenolysis. Adv. Synth. Catal. 2008, 350, 565-569. (d) Bheeter, C. B.; Jin, R.; Bera, J. K.; Dixneuf, P. H.; Doucet, H. Palladium-Catalysed Dehydrogenative $s p^{3} \mathrm{C}-\mathrm{H}$ Bonds Functionalisation into Alkenes: A Direct Access to N-Alkenylbenzenesulfonamides. Adv. Synth. Catal. 2014, 356, 119-124.

(11) Barder, T. E.; Walker, S. D.; Martinelli, J. R.; Buchwald, S. L. Catalysts for Suzuki-Miyaura Coupling Processes: Scope and Studies of the Effect of Ligand Structure. J. Am. Chem. Soc. 2005, 127, 46854696.

(12) Pan, J.; Su, M.; Buchwald, S. L. Palladium(0)-Catalyzed Intermolecular Amination of Unactivated $\mathrm{C}_{\mathrm{sp} 3}-\mathrm{H}$ Bonds. Angew. Chem., Int. Ed. 2011, 50, 8647-8651.

(13) Tan, B.; Bai, L.; Ding, P.; Liu, J.; Wang, Y.; Luan, X. PalladiumCatalyzed Intermolecular $[4+1]$ Spiroannulation by $\mathrm{C}\left(\mathrm{sp}^{3}\right)-\mathrm{H}$ Activation and Naphthol Dearomatization. Angew. Chem., Int. Ed. 2019, 58, 1474-1478.

(14) Rocaboy, R.; Anastasiou, I.; Baudoin, O. Redox-Neutral Coupling between Two $\mathrm{C}\left(\mathrm{sp}^{3}\right)-\mathrm{H}$ Bonds Enabled by 1,4-Palladium Shift for the Synthesis of Fused Heterocycles. Angew. Chem., Int. Ed. 2019, 58, 14625-14628.

(15) Chaumontet, M.; Piccardi, R.; Audic, N.; Hitce, J.; Peglion, J.L.; Clot, E.; Baudoin, O. Synthesis of Benzocyclobutenes by Palladium-Catalyzed C-H Activation of Methyl Groups: Method and Mechanistic Study. J. Am. Chem. Soc. 2008, 130, 15157-15166.

(16) Gutiérrez-Bonet, A.; Juliá-Hernández, F.; de Luis, B.; Martin, R. Pd-Catalyzed $\mathrm{C}\left(\mathrm{sp}^{3}\right)-\mathrm{H}$ Functionalization/Carbenoid Insertion: All Carbon Quaternary Centers via Multiple C-C Bond Formation. J. Am. Chem. Soc. 2016, 138, 6384-6387.

(17) (a) Lafrance, M.; Gorelsky, S. I.; Fagnou, K. High-Yielding Palladium-Catalyzed Intramolecular Alkane Arylation: Reaction Development and Mechanistic Studies. J. Am. Chem. Soc. 2007, 129, 14570-14571. (b) Kefalidis, C. E.; Baudoin, O.; Clot, E. DFT Study of the Mechanism of Benzocyclobutene Formation by Palladium-Catalysed $\mathrm{C}\left(\mathrm{sp}^{3}\right)-\mathrm{H}$ Activation: Role of the Nature of the Base and the Phosphine. Dalton Trans. 2010, 39, 10528-10535. (c) Rousseaux, S.; Gorelsky, S. I.; Chung, B. K. W.; Fagnou, K. Investigation of the Mechanism of $\mathrm{C}\left(\mathrm{sp}^{3}\right)-\mathrm{H}$ Bond Cleavage in $\operatorname{Pd}(0)$-Catalyzed Intramolecular Alkane Arylation Adjacent to Amides and Sulfonamides. J. Am. Chem. Soc. 2010, 132, 10692-10705. (d) Rousseaux, R.; Davi, M.; Sofack-Kreutzer, J.; Pierre, C.; Kefalidis, C. E.; Clot, E.; Fagnou, K.; Baudoin, O. Intramolecular PalladiumCatalyzed Alkane $\mathrm{C}-\mathrm{H}$ Arylation from Aryl Chlorides. J. Am. Chem. Soc. 2010, 132, 10706-10716. (e) Kefalidis, C. E.; Davi, M.; Holstein, P. M.; Clot, E.; Baudoin, O. Mechanistic Study on the Selectivity of Olefin versus Cyclobutene Formation by Palladium(0)-Catalyzed Intramolecular $\mathrm{C}\left(\mathrm{sp}^{3}\right)-\mathrm{H}$ Activation. J. Org. Chem. 2014, 79, 1190311910.

(18) (a) McNally, A.; Haffemayer, B.; Collins, B. S. L.; Gaunt, M. J. Palladium-Catalysed $\mathrm{C}-\mathrm{H}$ Activation of Aliphatic Amines to Give Strained Nitrogen Heterocycles. Nature 2014, 510, 129-133. (b) He, C.; Gaunt, M. J. Ligand-Enabled Catalytic C-H Arylation of Aliphatic Amines by a Four-Membered-Ring Cyclopalladation Pathway. Angew. Chem., Int. Ed. 2015, 54, 15840-15844. (c) Su, B.; Bunescu, A.; Qiu, Y.; Zuend, S. J.; Ernst, M.; Hartwig, J. F. Palladium-Catalyzed Oxidation of $\beta-\mathrm{C}\left(\mathrm{sp}^{3}\right)-\mathrm{H}$ Bonds of Primary Alkylamines through a Rare Four-Membered Palladacycle Intermediate. J. Am. Chem. Soc. 2020, 142, 7912-7919.

(19) Gutiérrez, E.; Nicasio, M. C.; Paneque, M.; Ruiz, C.; Salazar, V. Synthesis and Reactivity of New Palladium Alkyl Complexes
Containing $\mathrm{PMe}_{3}$ Ligands: Insertion Reactions and Formation of Bis(pyrazolyl)borate Derivatives. J. Organomet. Chem. 1997, 549, $167-176$.

(20) Cámpora, J.; López, J. A.; Palma, P.; del Rio, D.; Carmona, E.; Valerga, P.; Graiff, C.; Tiripicchio, A. Synthesis and Insertion Reactions of the Cyclometalated Palladium-Alkyl Complexes Pd$\left(\mathrm{CH}_{2} \mathrm{CMe}_{2}-\mathrm{o}-\mathrm{C}_{6} \mathrm{H}_{4}\right) \mathrm{L}_{2}$. Observation of a Pentacoordinated Intermediate in the Insertion of $\mathrm{SO}_{2}$. Inorg. Chem. 2001, 40, 4116-4126.

(21) The opening of five-membered palladacycle $\mathbf{C}^{1}$ under carbonate-mediated conditions was indirectly observed through the formation $\mathrm{BCB}$ isomers and deuterium incorporation on the aryl ring. ${ }^{15}$

(22) 2-Aryl cyclopropane-fused $\gamma$-lactones: (a) Milewska, M. J.; Gdaniec, M.; Polonski, T. Synthesis, Stereochemistry, and Chiroptical Spectra of Cyclopropyl Lactones and Thionolactones. Tetrahedron: Asymmetry 1996, 7, 3169-3180. (b) Muraoka, O.; Tanabe, G.; Momose, T. Accentuation of the Di-p-Methane Reactivity by Central Carbon Substitution in the 4-(Phenylmethyl)-2(5H)-furanone. Heterocycles 1990, 31, 1589-1592.

(23) (a) Shuto, S.; Ono, S.; Hase, Y.; Kamiyama, N.; Matsuda, A. Synthesis of (+)- and (-)-milnaciprans and their conformationally restricted analogs. Tetrahedron Lett. 1996, 37, 641-644. (b) Doyle, M. P.; Hu, W. A New Enantioselective Synthesis of Milnacipran and an Analogue by Catalytic Asymmetric Cyclopropanation. Adv. Synth. Catal. 2001, 343, 299-302.

(24) 1-Aryl cyclopropane-fused $\gamma$-lactams: Wang, K.-B.; Ran, R.-Q.; Xiu, S.-D.; Li, C.-Y. Synthesis of 3-Aza-bicyclo[3.1.0]hexan-2-one Derivatives via Gold-Catalyzed Oxidative Cyclopropanation of $\mathrm{N}$ Allylynamides. Org. Lett. 2013, 15, 2374-2377.

(25) Pedroni, J.; Cramer, N. Enantioselective C-H Functionalization-Addition Sequence Delivers Densely Substituted 3Azabicyclo[3.1.0]hexanes. J. Am. Chem. Soc. 2017, 139, 1239812401.

(26) Zhang, Z.-Z.; Han, Y.-Q.; Zhan, B.-B.; Wang, S.; Shi, B.-F. Synthesis of Bicyclo[n.1.0]alkanes by a Cobalt-Catalyzed Multiple $\mathrm{C}\left(\mathrm{sp}^{3}\right)-\mathrm{H}$ Activation Strategy. Angew. Chem., Int. Ed. 2017, 56, 13145-13149.

(27) Yoshida, Y.; Naoe, Y.; Terauchi, T.; Ozaki, F.; Doko, T.; Takemura, A.; Tanaka, T.; Sorimachi, K.; Beuckmann, C. T.; Suzuki, M.; Ueno, T.; Ozaki, S.; Yonaga, M. Discovery of $(1 R, 2 S)-2-\{[(2,4-$ Dimethylpyrimidin-5-yl)oxy]methyl $\}$-2-(3-fluorophenyl)- $\mathrm{N}$-(5-fluoropyridin-2-yl)cyclopropanecarboxam ide (E2006): A Potent and Efficacious Oral Orexin Receptor Antagonist. J. Med. Chem. 2015, $58,4648-4664$.

(28) Gao, R.; Fan, R.; Canney, D. J. Synthesis of $\beta, \beta$-Disubstituted $\gamma$ Butyrolactones by Chemoselective Oxidation of 1,4-Diols and $\gamma$ Hydroxy Olefins with $\mathrm{RuCl}_{3} / \mathrm{NaIO}_{4}$. Synlett 2015, 26, 661-665.

(29) Li, G.; Ji, C.-L.; Hong, X.; Szostak, M. Highly Chemoselective, Transition-Metal-Free Transamidation of Unactivated Amides and Direct Amidation of Alkyl Esters by $\mathrm{N}-\mathrm{C} / \mathrm{O}-\mathrm{C}$ Cleavage. J. Am. Chem. Soc. 2019, 141, 11161-11172. 